\title{
COERCED STERILIZATION AS A REPRODUCTIVE RIGHTS VIOLATION
}

D0I: 10.36740/WLek202012233

\author{
Volodymyr lemelianenko, Gornostay Alesia, Maslak Nataliya \\ YAROSLAV MUDRYI NATIONAL LAW UNIVERSITY, KHARKIV, UKRAINE
}

\begin{abstract}
The aim: To outline and systematize the issues related to violations and restrictions on the realization of the right to reproduction. To develop propositions and recommendations on improving the prevention and combating various manifestations of coerced sterilization.

Materials and methods: Theoretical basis for studying this issue includes scientific publications, research of the legislative systems of different countries, the conclusions of international non-governmental organizations. The authors of the paper have also taken into account international regulations, including UN Conventions and Directives, decisions of the European Court of Human Rights (ECHR), as well as analytical data provided by international organizations. Determinants in the study of this problem are the analysis, synthesis and generalization of the experience and legislative base of foreign countries, which are closely related to formal and comparative methods. Systematic, structural, dialectical and statistical methods have been also used in this paper to substantiate the problem of sterilization.

Conclusions: The most radical decision to refuse from reproduction is surgical sterilization (defertilization). It can be classified as voluntary, forced and coerced. The problems of preventing and combating coerced sterilization are among the most difficult ones. Bribery and mental coercion of persons in order to obtain consent for sterilization are either not regulated by law and do not entail any liability, including criminal, or even are part of the state government policy to regulate the number of citizens in overpopulated countries, HIV-infected people, including prisoners or transgender people.
\end{abstract}

KEY WORDS: reproductive rights, coerced surgical sterilization, coerced sterilization of convicts, coerced sterilization of transgender people

Wiad Lek. 2020;73(12 p. II):2902-2908

\section{INTRODUCTION}

A person has reproductive rights from the moment of birth, they are part of the private life sphere and belong to the category of natural and inalienable, so their protection must be ensured both at national and international levels. However, there is a problem of coerced sterilization in trerms of the right of not interfering human reproductive activities existence.

The right to reproduce one's kind is inherent in many other human rights. The case law and experience of human rights organizations illustrate that reproductive rights are often a context, where such inalienable human rights as the right to life and health, the right to dignity, the right to liberty and security of person, and the right to non-interference in family and private life, as well as the prohibition of torture, inhuman or degrading treatment are violated. The emergence of regressive tendencies in some states and the attempts of some governments to exercise control over the realization of the right to reproduction of certain socially vulnerable groups is of concern. The free exercise of a person's right to reproduction, especially in the medical, social and legal aspects remains an urgent problem for the whole world community. Coerced sterilization is the violation of the natural human right to reproduce one's kind. This type of sterilization occurs under the pressure of psychological, political, material circumstances. Many states either contribute financially to this phenomenon or establish discriminatory rules against those who do not wish to undergo this medical procedure. Convicted persons, transgender people, HIV-infected persons and representatives of the poorest layers of the population in overpopulated regions, such as India, Peru and others, are subject to coerced sterilization.

The existence of this problem is also due to insufficient legal regulation, gaps in solving the problem of the responsibility for bribery or mental coercion to sterilization, which leads to profanity, so we can overcome obstacles to human reproductive rights only by eliminating or reducing the negative impact of these factors.

\section{THE AIM}

The aim of this article is to define the concept of coerced sterilization and structuring of its varieties; to research the problems and the status of protecting the realization of reproductive rights both at national and international levels; to suggest the ways on improving the prevention and punishment of cases of forcing individuals to renounce the right to reproduce one's kind.

\section{MATERIALS AND METHODS}

This research is based on the analysis of the experience and legislation of such countries as Ukraine, Great Britain, 
Central America and Africa countries, USA, Germany, China, Uzbekistan, Tunisia, Singapore, India, Czech Republic, Japan, Sweden, illustrating the coercion of persons to surgical sterilization. The empirical basis of the research also consists of the UN, WHO and other international and governmental organizations' international legal acts, laws, decisions of the European Court of Human Rights (ECHR). In addition, the authors have used statistics from international organizations, expert opinions, doctrinal ideas and views on this issue.

The analysis of scientific sources demonstrates that the issues for the realization of reproductive human rights are covered in the studies of Pashkov V., Gutorova N., Horodovenko V., Lyfar A., Biletska E. and others $[1 ; 2 ; 3 ; 4]$. However, the concepts of coerced sterilization, the allocation of its types, grounds and problematic issues of its legal regulation were not the subject of a separate thorough study. The methodological basis of the study consists of general scientific and special methods. The authors of the paper use dialectical, statistical, formal, comparative methods and method of generalization. Historical and logical methods are also used to study the essence of the problematic issues and to develop sound recommendations for their solution.

\section{REVIEW AND DISCUSSION}

The idea of reproductive rights as human rights is new and comprehensive. If we recognize that every person can freely enjoy and use their fundamental rights guaranteed by the Constitution, the Convention for the Protection of Human Rights and Fundamental Freedoms, the Universal Declaration of Human Rights, then we recognize that everyone has the right to freely exercise and control their reproductive life.

The realization of person's reproductive rights means that everyone has the right to reproduce and the freedom to decide when and how often to do so or not to do it at all. It also means that everyone has the right to decide on reproduction without discrimination, coercion and violence $[5, \S 7.2-7.3]$.

When a person is coerced to renounce his or her reproductive rights, he or she is restricted from disposing his or her private life, protecting own health, and exercising his or her rights as a person and as a citizen.

The right to reproduction is important for the realization of a wide range of fundamental human rights, in particular the human right to life and health, respect for dignity, freedom and personal integrity, non-interference in family and private life, and the prohibition of torture and inhuman or degrading treatment. These rights cannot be effectively protected without guaranteeing that everyone can independently determine when, how and whether to have children, to control own reproductive function, to obtain access to important information and services on reproductive health and be free from violence and coercion in this area.

Natural and inalienable human rights cannot be fully realized without guaranteeing the freedom of reproductive choice. In turn, reproductive rights derive their meaning and strength from long-recognized human rights [6].
The most radical decision to refuse from reproduction is surgical sterilization (defertilization), which is a medical manipulation aimed at depriving fertility. As a result of surgery a person usually permanently loses reproductive function.

In general, sterilization can be divided into types depending on the will of the person to whom it is applied:

forced sterilization is a medical manipulation that is carried out against the will (with disregard of the will) of a person using deception or physical violence;

voluntary sterilization is a medical manipulation that is carried out on the voluntary, conscious and aware initiative or consent of a person [7];

coerced sterilization is a medical manipulation performed to a person who although agrees to perform it, but his or her will is significantly affected under the pressure of circumstances. Methods of involuntary sterilization are bribery and mental coercion. Involuntary sterilization, its types and methods are the subject of this research.

Many countries in the modern world encourage sterilization by financial means or force to it by establishing discriminatory rules for a fertile people.

Involuntary sterilization can be divided into types according to the range of persons to whom it is applied (HIV-infected, drug addicts, transgender people, prisoners, sterilization of the poorest layers of the population in overpopulated countries).

Involuntary sterilization of $\mathrm{HIV}$-infected people and drug addicts is a marginalizing practice used wordwide, especially in countries with a high incidence of HIV.

Thus, the non-profit American organization Project Prevention pays women who use drugs for their sterilization. More than 1,300 women had been sterilized up to 2010. The project expanded its activities to the United Kingdom and Kenya in 2010. Project founder Barbara Harris is offering women living with HIV USD \$ 40 for the IUD installation and USD \$ 300 for sterilization $[8,9,10]$.

The practice of involuntary sterilization of this category of persons has been recorded in a number of countries such as the Dominican Republic, Venezuela, Chile, El Salvador, Honduras, Mexico and Nicaragua. A survey of 285 women living with HIV from four Central American countries (El Salvador, Honduras, Mexico and Nicaragua) in 2015 found that about $25 \%$ of them were under pressure from health care professionals [11]. Health care professionals informed women in order to sterilize them that their HIV status revoked their right to choose another method of contraception and refused to provide them medical services needed to prevent vertical transmission of HIV in the event of denial.

But the most widespread cases of coerced sterilization of HIV-infected people occur in Africa. In Namibia, health care professionals threatened to ban an infected person to communicate with children or refused to perform an abortion if a person did not agree to sterilization [12]. In South Africa women are threatened with discontinuation of giving essential antiretroviral drugs if they do not sign a sterilization consent form [13]. 
Governmental and non-governmental organizations often encourage patients' consent to sterilization in this way. They justify involuntary sterilization on medical grounds, saying that HIV-positive or drug-addicted persons should be sterilized to reduce the transmission of HIV from mother or father to children and to prevent the birth of children with physical or mental disabilities of drug-addicted parents. However, it seems that this procedure violates not only the principle of medical ethics, but also usefulness, because the treatment should be useful for the patient. Sterilization is not required for this. Back in the 1990s, inexpensive drugs were developed for antiretroviral treatment that reduced the risk of mother-to-child transmission of HIV to less than 2 percent. Those drugs are available even to the poorest layers of the population and to countries with underdeveloped health care systems [13]. In addition to sterilization, there is currently a large number of alternative contraceptives. That is the reason that bribing or mental coercion of patients in order to obtain their consent to sterilization is a gross violation of natural human rights and cannot be justified.

Involuntary sterilization of criminals is a medical manipulation offered to criminals in exchange for shortening the sentence or mitigating the conditions of serving it. This research deals with sterilization, which is an irreversible procedure and does not involve the restoration of the reproductive functions of criminals. Quite a large number of countries apply drugs that suppress sexual function for some period of time to criminals (pedophiles, rapists), but such procedures are not the subject matter of this research because these functions are restorable.

A person receives an offer to perform sterilization operation in exchange for release from punishment or mitigation of punishment, it should be considered an influence on his will. This procedure deprives a person of the ability to reproduce and causes serious physical and psychological disorders. That is why the surgical castration of criminals, for all its external voluntariness, must be recognized as involuntary and identified as a violation of human reproductive rights.

Involuntary sterilization of transgenderpeople is a medical manipulation that is mandatory for legal gender reassignment of transgender people.

The most pressing issue of involuntary sterilization in the modern world is the existence of laws on mandatory sterilization of transgender people in many countries. They require that transgender people must be sterilized before they can legally change their sex.

The Committee of Ministers of the Council of Europe Recommendation, adopted in 2010, calls for "appropriate measures to ensure full legal recognition by any person's change of gender in all spheres of life, in particular, by enabling them to change gender and name in official document in a prompt, transparent and accessible manner" [14]. The Yogyakarta Principles for the Application of International Human Rights Law on Sexual Orientation and Gender Identity also emphasize: "No one may be coerced to undergo gender reassignment, sterilization, or hormone therapy as a prerequisite for the legal recognition of gender identity" [15].
Nowadays, there are countries in the world which do not require surgery for legal gender reassignment; there are countries, where such a procedure is mandatory. For example, the Art. 51 of the Fundamentals of the legislation of Ukraine on health care notes that the issue of relevant changes in the legal status of a transgender person is resolved on the basis of a medical certificate of gender reassignment [16]. The Art. 257 of the Marriage and Family Code of Kazakhstan stipulates that transgender people can change their name, last name and middle name according to the chosen gender only after surgical correction of sex [17]. The Order of the Minister of Health Care and Social Development of the Republic of Kazakhstan No. 187 on approval of the Rules of medical examination and gender reassignment for persons with sexual identification disorders in 2015 also confirmed the mandatory nature of surgical correction of sex [18].

The bill on Transgender People Rights Protection of 2019 in India also provides that a person may apply to change his or her legal gender to male or female, but it requires prompt intervention as evidenced by medical records [19].

The high-profile case of Takakito Usui, a 43-year-old transgender man (that is, one who was born a woman, but identifies himself as a man), who wants to be recognized as a man in the Japanese population and marital registry, is currently widely covered in Japan. However, he must remove his ovaries and uterus according to the law, as well as to make surgery that his genitals look like male ones, to be over 20 years old, single, having no minor children and be diagnosed with a "gender identity disorder". Takakito Usui wanted to obtain a new documents proving his masculine identity without sterilization, but he was refused. The man filed a lawsuit on family cases and the court rejected his application. The court concluded that the preservation of the reproductive function of an individual of the appropriate sex, obtained by him or her at birth, is impractical after gender correction [20]. More than 7,800 Japanese have been forcibly sterilized to obtain legal recognition of their desired sex since the adoption of the law in 2004.

Activists and opponents of this approach call these laws aggressive and contrary to the human right to self-identification. The European Court of Human Rights stated in 2017 that 22 countries, which are under its jurisdiction, still require sterilization as part of a legal gender reassignment.

In 2017 judgment in A.P., Garçon and Nicot v. France, the European Court of Human Rights held that the French law provision requirement that transgender persons undergo a sterilization procedure or other medical treatment before changing the gender identity on their birth certificates violated their rights to respect for private life [21]. The European Committee of Social Rights found a similar requirement in the Czech Republic to violate the European Social Charter [22].

Laws on the coerced sterilization of transgender people are unconstitutional because they violate human rights and guarantees of respect for one's identity. Many transgender people do not have the opportunity to undergo sterilization and surgical correction due to the lack of health, 
financial resources or unwillingness to lose reproductive function. Besides, the use of invasive surgery is a serious interference in the body and can cause serious physical harm. Therefore, the decision on such a surgery should be completely voluntary without any pressure from the state. Progressive European countries that abandoned the practice of compulsory surgical sex reassignment have acknowledged that they violated the reproductive rights of their citizens in the past. Thus, the Swedish Parliament on March 21, 2018 decided to pay compensation to those people who were coerced to undergo sterilization for legal gender reassignment. This is approximately 600-700 people who are entitled to compensation in the amount of 22,500 euros [23]. Sweden became the first country that compensated transgender people for serious violations of their natural reproductive rights.

Involuntary sterilization in overpopulated countries and members of national minorities is a medical manipulation offered to individuals in exchange for material rewards or by imposing discriminatory restrictions on those who do not wish to lose fertility. This type of involuntary sterilization is very often a part of some countries' government policy.

For example, involuntary sterilization in China was used until 2017 as a part of the "one child policy". The motives were to provide financial incentives and employment opportunities for those who adhered to them, and to impose sanctions (economic or others) on those who violated this policy. A similar situation exists today in Uzbekistan, where some women are reported to be required to present a "sterilization certificate" while being employed [24]. Governmental financial assistance in Tunisia covered only the first four children. Income tax benefits, maternity leave, the allocation of public apartments and school places were applied only to the first three children in Singapore, [25].

The United States Congressional-Executive Commission on China (CECC) found out that the Chinese authorities used the revocation of state benefits and permits, as well as the abolition of registration for unsterilized women and their children as a coercion to be sterilized [26]. The family planning authorities in Puning launched on April 7, 2010 a 20 -day campaign to conduct 9,599 sterilizations. Punitative authorities detained 1,377 people who are parents or relatives of the targets who were subjected to sterilization for obvious pressure. The Amnesty International Foundation accused the Puning City authorities in 2010 for forcing people to be sterilized by imprisoning their elderly relatives [26]. Since their adult children refused to be sterilized, they were kept until the children agreed to be sterilized. Many of the detainees were in appalling conditions, in cramped rooms with high humidity, where there was no room even to sit down [26].

Public sterilization clinics were officially active in India until 2017, where various financial incentives and compensations were offered to those who would undergo sterilization. The government raffled off various prizes, starting from the Tata Nano (one of the cheapest vehicles in the world) up to motorcycles, mixers and TVs among those who were sterilized. About 4 million sterilizations were performed only in 2013-2014 in India. Less than 100,000 of those surgeries were performed on men [27].

Does the government have the right to restrict the freedom and rights of a person to have the desired number of children? Is it justified to use its socio-economic mechanisms of influence to achieve the goals of population control? Are there any restrictions on this type of "influence"? Proponents of population control argue that population control is necessary to combat global poverty and the continuing deterioration of the environment.

If the government forces its citizens to be sterilized by imposing discriminatory restrictions on fertile persons, this can undoubtedly be considered as the violation of the inalienable human right to reproduction. At the same time, the use of material incentives such as money, food, clothing and other material benefits to motivate the population to sterilization also raises serious ethical issues. Studies have shown that those incentives work best for the very poor and uneducated layers of the population. Such individuals are economically vulnerable due to poverty and often do not understand the full essence and consequences of this manipulation due to the lack of education.

Control of the population through bribery and blackmail restricts human freedoms and is contrary to the natural rights to reproductive health enshrined in the UN Declaration of Human Rights.

New studies demonstrate that population growth is often accompanied by an increase in resources. Moreover, economic development leads to lower birth rates without the need for severe population control measures. It is now well documented that as countries become richer, citizens of such countries tend to choose fewer children in the family on their own. This phenomenon is called the birth transition [28].

Governments should invest in family planning and population control programs that establish ethical guidelines for improving public education on these issues, as well as contain information on alternative contraceptives. Such measures will avoid unnecessary ethical dilemmas and conflicts.

Another form of pressure on the poorest layers of population and national minorities is forcing them to sign a sterilization agreement, at the moment when it was not expected that individuals would be able to make an informed and balanced decision. Thus, women during childbirth are asked to immediately decide on sterilization and asked to sign a consent form, sometimes written by hand, in difficult to understand language, or using unfamiliar terms, or terms in Latin [29]. In Indian sterilization camps in Uttar Pradesh state, poor illiterate women undergo a consent procedure in a hurry. Women were only informed about sterilization, without mentioning any other possible longterm method of family planning. They were asked to leave a fingerprint without reading the content of the suggested form or without fully explaining the essence of the procedure. The Indian government reportedly paid private physicians for every done sterilization. For example, the Santushti Foundation offered to pay Rs 15,000 per surgery, and hospitals and clinics an additional Rs 500 per case, 
when 30 surgeries are performed in one day in an inpatient facility. This practice created a powerful incentive for physicians to force sterilization [30].

Government family planning programs in Uzbekistan have also led to the situation, when physicians force wemen to agree to sterilization in order to receive bonuses [31]. In response to such incidents, the International Federation of Obstetricians and Gynecologists (FIGO), the world's only professional organization for obstetricians and gynecologists, has adopted an ethical guidelines that emphasize that sterilization is a voluntary procedure; that patients should be informed that sterilization is irreversible; that sterilization can never be justified by emergency medical care; that consent to sterilization should never be a condition of receiving other medical care or any benefits [32]. Thus, respect for the autonomy of sterilization decisions requires that any counseling, advice, or information provided by health care providers or any other support to health care professionals or family members should be impartial. Practitioners and the public should be aware that only clear, accessible and understandable instructions will ensure a person's full, free and informed consent to sterilization [33]. This will allow the person to make the best decision for him or her, realizing that the final sterilization is an irreversible procedure.

The European Court of Human Rights also emphasizes the need for free and informed consent while deciding on sterilization. Thus, the ECHR in the case of N.B. v. Slovakia (No. 29518/10) dated June 12, 2012 found a violation of the applicant's rights, who although voluntarily signed sterilization agreement, but that agreement was not complete and final [34].

Analyzing the different types of involuntary sterilization in relation to the range of persons to whom it is applied (recipients), it should be noted that involuntary sterilization can also be differentiated by other criteria that contain its essential features, such as subjects (agents) of application, methods, goals, degree of compulsion. Thus, agents of application (those who initiate the interference with a person's reproductive rights) are, first of all, the state, when involuntary sterilization is to some extent enshrined in state programs, regulatory acts, supported by government payments, etc. For example, the above-mentioned India with the legal requirement of legal gender reassignment only in the presence of surgical intervention and China with its "one child policy". In addition, the agent of applying involuntary sterilization is society, community in situations of "veiled" state intervention and the absence of the relevant regulations or concepts of "purity of the nation", "eugenic experiment", etc. Sterilization is implemented through the activities of certain non-governmental organizations or charitable foundations, such as in Kenya, the Dominican Republic and other countries, where the promotion of sterilization of HIV-infected people, as mentioned above, is widespread.

Involuntary sterilization, according to the methods of application, can be carried out by the assistance of both direct methods of the state (in the presence of the state-declared policy of population reduction) and indirect methods (when the policy of population reduction or application of involuntary sterilization to certain segments of the population is not directly declared, but is implemented in the way of incentives, bonuses or payments, for example, to physicians who make such sterilizations). Thus, genetic experiments on a national scale are in the past in conditions of the rise of worldwide public awareness and the adoption of the concept of state compliance with the minimum standard of human rights. However, some states use "indirect" methods to encourage people related to reproduction (physicians, obstetricians, social workers) to "gently" induce certain layers of the population to be sterilized. This also may include cases of material incentives for the recipients of involuntary sterilization, such as payment of monetary compensation or participation in the lottery, like in India until 2017.

According to the goals that society / state puts before involuntary sterilization, one can distinguish them as clearly "socially useful", such as:

- the health of the nation (with involuntary sterilization of HIV-infected people);

- security of society (with involuntary sterilization of vulnerable groups, including high crime rate, homeless people, prone to alcohol or drug addiction, etc.);

- special prevention (for criminals who committed sexual crimes);

- legal certainty (regarding the gender status of transgender people),

and clearly doubtful goals (genetic, eugenic "purity of the nation" programs or current genetic "biohacking" concepts that promote sterilization as a preventive measure against certain hereditary and genetic diseases, such as cervical cancer, ovarian cancer, as well as a mean of prolonging youth, etc.).

It seems that coerced sterilization, in contrast to both voluntary and forced, can have certain degrees of compulsion, and can be divided into:

- absolutely coerced (for example, sterilization of transgender people);

- relatively coerced (HIV-infected, sterilization for benefits, etc.).

Thus, all the above-mentioned types of sterilization, which we refer to coerced, have common features - they are carried out to a person who, although gives consent to their implementation, but the will is limited, is significantly affected by the pressure of circumstances, bribery, mental coercion, bureaucratic or legal rules, procedures and regulations, policies of the state and society, and therefore can not be considered fully voluntary, and is not forced, because it is carried out with the formal, but the consent of the person.

\section{CONCLUSIONS}

Thus, coerced sterilization does not clearly meet the requirements and standards for human rights and fundamental freedoms and is often a measure of the state that significantly 
restricts or deprives a person of the right, including reproductive rights, and does not clearly comply with the principle of proportionality that is used, in particular, in the practice of the ECHR, and despite being used for a legitimate purpose and lawful means of intervention (which is often not observed in coerced sterilization) also violates the requirements of propriety, reasonableness and balance, which constitute the proportionality in its narrow sense.

The right to reproduce, in the current democratic society, as an inalienable natural right of every human being should not be subject to any restrictions. The decision not to reproduce must be entirely voluntary, and a person receiving it must not be bribed or pressured by either the state or other persons. Besides, the irreversibility of the surgical sterilization procedure imposes on the state the obligation to ensure that the person's consent to this procedure is complete, informed and uncoerced.

Human rights can give states a powerful incentive, legal commitment, and a wide range of strategies that allow implementing changes - to identify violations, to rethink public perceptions, and to overcome economic and social barriers to reproductive health protection. Governments must begin to search ways to improve their legal and regulatory frameworks to ensure unresisted realization of everyone's own reproductive rights. The use of human rights as a tool to identify the necessary changes will ensure effective protection of the right to reproduction. It is quite difficult to prosecute coerced sterilization from the legal point of view, because the person outwardly seems to voluntarily agree to such a procedure, although under the pressure of certain circumstances - financial incentives or the threat of certain oppression of the rights. In addition, the legislation of many countries does not consider the promotion of sterilization as a crime. The governments of such states may subsequently apologize and offer financial compensation to victims of coerced sterilization policies. But there are exceptions - for example, Part 4 of the Art. 134 of the Criminal Code of Ukraine provides criminal liability for coercion to sterilization and it is the latest decision, but hardly successful, since the term "coercion" is not revealed and can be interpreted very broadly, hardening the separation of coerced sterilization from forced one, etc.

It seems that states in order to prevent cases of coerced sterilization can take the following measures:

1) purposeful active policy of the states' governments in regard to unimpeded realization of the right to reproduction;

2) reduction of regulatory differences and unregulations in the field of reproductive health protection through legislative amendments;

3) establishment of criminal and other types of liability for the violation of patients' reproductive rights and, in particular, for coerced sterilization;

4) protection of the patient-physician relationship. The relationships between patients and their physicians are focused on trust and confidentiality. Probably, these principles are more important in the field of reproductive health than in any other field. It often involves intimate, difficult conversations and decisions, when patients are highly dependent on the opinion of the physician;

5) strengthening comprehensive sex education. Ensuring that adolescents and young people have the resources and knowledge to have sexually healthy lives and reproduction, which is an important component of their educational and social development;

6) support and funding for family planning centers that offer medically accurate information and quality care. Such centers help women to take decisions about birth and the number of children through awareness of contraceptives, pregnancy testing, counseling for sexually transmitted diseases, etc.;

7) encouragement of the states to protect and expand their medical programs in the field of protecting the realization of reproductive rights by human beings.

\section{REFERENCES}

1. Pashkov V., Hutorova N., Noha P. Reproductive function: the protection of the rights of the people wich are sent to the area of the fighting. Wiad. Lek. 2018, 2: 403-407.

2. Biletska E., Onul N. et al. Current tendencies in the nutrition of women and pregnant women of industrial region of Ukraine and their influence on microelements supply. Wiad. Lek. 2018, 4: 843-848.

3. Pashkov V., Lyfar A. Assisted reproductive technologies: the problems of legal enforcement. Wiad. Lek. 2018, 5: 1066-1070.

4. Horodovenko V., Pashkov V., Udovyka L.: Protection of patients' rights in the European Court of Human Rights. Wiad. Lek. 2018, 6: 1200-1206.

5. Programmer of action of the International conference on population and development (ICPD) Cairo, Egypt 5/13/1994. Available from: https://www. unfpa.org/sites/default/files/pub-pdf/icpd_rus.pdf [reviewed 2020.08.12].

6. Reproductive Rights are Human Rights. 2009. Center for Reproductive Rights. Available from: https://reproductiverights.org/sites/default/ files/documents/RRareHR_final.pdf [reviewed 2020.08.12].

7. Volodymyr V. lemelianenko, Alesia V. Gornostay, Alona V. Ivantsova Reproductive rights violations: forced sterilization and restriction of voluntary sterilization) / Wiad Lek 2019;72;12 cz. II: 2536-2540.

8. Project Prevention. Available from: http://www.projectprevention.org/ [reviewed 2020.08.12].

9. Prevention of mother-to-child transmission (pmtct) of HIV. Available from: https://www.avert.org/professionals/hiv-programming/ prevention/prevention-mother-child [reviewed 2020.08.22].

10. Against her will. Forced and coerced sterilization of women worldwide. Open Society Foundations. Available from: https://www. opensocietyfoundations.org/uploads/62505651-2c58-4c12-a61046499e645a2c/against-her-will-20111003.pdf [reviewed 2020.08.22].

11. T. Kendall, C. Albert Experiences of coercion to sterilize and forced sterilization among women living with HIV in Latin America/ Journal of the International AIDS Society, 18 2015: 19462.

12. Baumgarten Robin. "Forced and coerced sterilisation: violating the rights of women living with HIV.» Sister Namibia, 2009; 21; 2, Available from: https://www.opensocietyfoundations.org/voices/ women-namibia-fight-back-against-forced-sterilization [reviewed 2020.08.22].

13. Stephanie Bi and Tobin Klusty. Forced Sterilizations of HIVPositive Women: A Global Ethics and Policy Failure. AMA J Ethics. 2015;17(10):952-957. doi: 10.1001/journalofethics.2015.17.10. pfor2-1510. 
14. Council of Europe Recommendation CM/Rec(2010)5 of the Committee of Ministers to member states on measures to combat discrimination on grounds of sexual orientation or gender identity. Available from: https://wcd.coe.int/ViewDoc.jsp?id=1606669 [reviewed 2020.08.22].

15. Additional Principles and State Obligations on the Application of International Human Rights Law in Relation to Sexual Orientation, Gender Identity, Gender Expression and Sex Characteristics to Complement the Yogyakarta Principles. Available from: http:// yogyakartaprinciples.org/ [reviewed 2020.08.22].

16. Osnovy zakonodavstva Ukrainy pro ohoronu zdorov'ya. 19/11/1992. №2801-XII. [Fundamentals of the legislation of Ukraine on health protection]. Available from: https://zakon.rada.gov.ua/laws/ show/2801-12 [reviewed 2020.08.30] (Ua).

17. Kodeks Respubliky Kazahstan "0 brake (supruzhestve) i semye" № 518-IV. [Code of the Republic of Kazakhstan "On marriage and family"]. Available from:https://online.zakon.kz/document/?doc_id=31102748 [reviewed 2020.08.30] (Ru).

18. Prikaz ministra zdravoohranniya i socialnogo razvitiya Respubliki Kazahstan № 187 "Ob utverzhenii Pravil medicinskogo osvidetelstvovaniya i provedeniya smeni pola dlya lic s rasstroistvamy polovoi identifikacii" [Order of the Minister of Health and Social Development of the Republic of Kazakhstan № 187 «0n approval of the rules of medical examination and gender reassignment for persons with gender identity disorders»]. Available from: https://online.zakon. kz/Document/?doc_id=32545001 [reviewed 2020.08.30] (Ru).

19. India: Transgender Bill Raises Rights Concerns. Human Rights Watch. Available from: https://www.hrw.org/news/2019/07/23/indiatransgender-bill-raises-rights-concerns [reviewed 2020.08.30].

20. "A Really High Hurdle" Japan's Abusive Transgender Legal Recognition Process. Human Rights Watch. Available from: https://www.hrw.org/ report/2019/03/19/really-high-hurdle/japans-abusive-transgenderlegal-recognition-process [reviewed 2020.08.30].

21. Case of A.P., Garçon and Nicot v. France, (nos. 79885/12 52471/13 52596/13), Judgment of 6 April 2017. Available from: https://hudoc. echr.coe.int/eng\#\{\%22itemid\%22:[\%22001-172556\%22]\} [reviewed 2020.08.30].

22. Case of Transgender Europe and ILGA-Europe v. the Czech Republic, (No. 117/2015) Judgment of 15 May 2018. Available from: https://hudoc. esc.coe.int/eng\#\{\%22sort\%22:[\%22ESCPublicationDate\%20Descendi ng\%22],\%22ESCDcldentifier\%22:[\%22cc-117-2015-dmerits-en\%22]\} [reviewed 2020.08.30].

23. Historic Victory for Trans People - the Swedish Parliament Decides on Compensation for Forced Sterilizations. RFSL. Available from: www. rfsl.se/en/aktuellt/historic-victory-trans-people-swedish-parliamentdecides-compensation-forced-sterilizations/https:/www.rfsl.se/en/ aktuellt/historic-victory-trans-people-swedish-parliament-decidescompensation-forced-sterilizations/ [reviewed 2020.08.30].

24. Mansur Mirovalev, "Uzbek Women Accuse State of Mass Sterilizations," The Independent, July 17, 2010.

25. de Silva Tiloka and Tenreyro Silvana. Population control policies and fertility convergence. Journal of Economic Perspectives, 31 (4):205-228 doi: $10.1257 /$ jep.31.4.205

26. Country Advice China China - CHN38886 - Forced sterilisation/ contraception - Guangdong Province - Childbearing age 29 June 2011. Australian Government. Refugee Review Tribunal. Available from: https://www.refworld.org/pdfid/4f13d60f2.pdf [reviewed 2020.09.03].
27. Soutik Biswas. India's dark history of sterilization. BBC. Available from: https://www.bbc.com/news/world-asia-india-30040790 [reviewed 2020.09.03].; Aruna Kashyap. Dispatches: Ending India's Sterilization 'Targets'. Human Rights Watch. Available from: https://www.hrw. org/news/2014/11/12/dispatches-ending-indias-sterilization-targets [reviewed 2020.09.03].

28. Komu, E. A., \& Ethelberg, S. N. Family planning and population control in developing countries: Ethical and sociocultural dilemmas. Online Journal of Health Ethics, 2015; 11(1) doi:10.18785/0jhe.1101.06

29. European Roma Rights Centre, Center for Reproductive Rights, and NEKI, A.S. v Hungary-Informed Consent: A Signature Is Not Enough 2008.

30. Jason Overdorf, "India Population: Is Sterilization the Answer?" Global Post, July 14, 2010.

31. Mansur Mirovalev, "Uzbek Women Accuse State of Mass Sterilizations," The Independent, July 17, 2010.

32. Forced Sterilization: The Hidden Human Rights Abuse. Heinrich-BöllStiftung. Available from: https://cz.boell.org/en/2014/07/10/forcedsterilization-hidden-human-rights-abuse [reviewed 2020.09.03].

33. OHCHR, UN Women, UNAIDS, UNDP, UNFPA, UNICEF and WHO. Eliminating forced, coercive and otherwise involuntary sterilization An interagency statement. Available from: https://www.unaids.org/sites/ default/files/media_asset/201405_sterilization_en.pdf [reviewed 2020.09.03].

34. Case of N.B. v. Slovakia (application no 29518/10), Judgment of 12 June 2012. Available from: https://hudoc.echr.coe.int/ eng\#\{\%22itemid\%22:[\%22001-111427\%22]\} [reviewed 2020.09.03].

This article is a part of the research program of the Department of Criminal Law of the Yaroslav Mudryi National Law University "Theoretical problems of efficiency of criminal legislation and practice of its application".

\section{ORCID and contributionship:}

Volodymyr Iemelianenko: 0000-0002-8999-3672 A, D, E, F

Alesia Gornostay: 0000-0003-0101-6808 A, B, D, E

Nataliya Maslak: 0000-0003-3824-8223 ${ }^{A, B, D}$

\section{Conflict of interest:}

Authors declare no conflict of interest.

\section{CORRESPONDING AUTHOR Volodymyr V. lemelianenko \\ Yaroslav Mudriy National Law University \\ Kharkiv, Ukraine \\ tel: +380501727091 \\ e-mail: don8@bigmir.net}

Received: 28.08 .2020

Accepted: 30.11 .2020

A - Work concept and design, B - Data collection and analysis, C - Responsibility for statistical analysis, D - Writing the article, $\mathbf{E}$ - Critical review, $\mathbf{F}$ - Final approval of the article 